\title{
IL-4 inhibits proliferation of renal carcinoma cells by increasing the expression of $\mathrm{p} 21^{\text {WAF1 }}$ and IRF-1
}

\author{
Su-Jin $Y u^{1,2,3}$, Hyeon Soo $\mathrm{Kim}^{1,2,3}$, \\ Sung-Won $\mathrm{Cho}^{4}$ and Jeongwon Sohn ${ }^{1,2,3,5}$ \\ ${ }^{1}$ Department of Biochemistry \\ College of Medicine \\ ${ }^{2}$ Graduate School of Biotechnology \\ ${ }^{3}$ Korea Nutrition Research Institute \\ ${ }^{4}$ Department of Parasitology \\ College of Medicine, Korea University \\ Seoul 136-705, Korea \\ ${ }^{5}$ Corresponding author: Tel, 82-2-920-6192; \\ Fax, 82-2-922-6702; E-mail, biojs@korea.ac.kr
}

Accepted 3 August 2004

Abbreviations: CDK, cyclin dependent kinase; IRF-1, interferon regulatory factor-1; RCC, renal cell carcinoma

\begin{abstract}
Interleukin (IL)-4 inhibits proliferation of several human cancer cell lines in vitro. Although IL-4 is known to regulate proliferation of lymphocytes by modulating $\mathrm{p} 27^{\mathrm{KIP} 1}$ expression, the mechanism involved in the IL-4-induced growth inhibition of nonhematopoietic cancer cells has not been fully elucidated. Previously, we reported that IL-4 suppressed proliferation of human renal cell carcinoma (RCC) cell lines in vitro. Here, we show that IL-4 inhibits cell cycle progression at the $\mathbf{G} 1$ phase in Caki-1 cells by increasing the expression of $\mathrm{p} 21^{\mathrm{WAF} 1}$ and interferon regulatory factor (IRF)-1, and decreasing the cyclin dependent kinase (CDK) 2 activity. Up-regulation of $p 21^{\text {WAF1 }}$ and IRF-1 expression is transcriptional, but independent of $p 53$. The levels of $p 21^{\text {WAF1 }}$ and IRF-1 proteins were enhanced as early as $1 \mathrm{~h}$ after IL-4 treatment. CDK2 activity started to decline at $4 \mathrm{~h}$ after IL-4 treatment, and by $24 \mathrm{~h}$, was $\sim 50 \%$ of the control. Neither the protein expressions of $\mathrm{p} 27^{\mathrm{KIP} 1}$ and $\mathrm{p} 16^{\mathrm{INK} 4 \mathrm{a}}$, nor the phosphorylation level of $\mathrm{pRb}$ was changed. The importance of $\mathrm{p} 21^{\mathrm{WAF} 1}$ and IRF-1 in the growth inhibition induced by IL-4 was confirmed by antisense oligonucleotide transfection. Both of $\mathrm{p} 21^{\mathrm{WAF} 1}$ and IRF-1 antisense oligonucleotides prevented IL-4-mediated growth
\end{abstract}

inhibition by $\sim 30 \%$ compared to the respective sense oligonucleotides. In summary, our study indicated that $\mathrm{p} 21^{\text {WAF1 }}$ and IRF-1 mediate the growth inhibitory effect of IL-4 in human RCC cells.

Keywords: IL-4; interferon regulatory factor-1; p21 ${ }^{\text {WAF1; }}$ renal cell carcinoma

\section{Introduction}

IL-4, originally found as a B cell growth factor, possesses pleiotropic effects including Th2 cell differentiation, and class switching to $\lg E$ and $\lg G 1$. IL-4 is produced by a subset of CD4 T cells, basophils and mast cells, and plays a central role in regulating differentiation and growth of lymphocytes (Brown and Hural, 1997). In early 1990s, IL-4 was shown to inhibit the growth of several cancers in vivo and the potential role of IL-4 in cancer therapy had been suggested (Tepper et al., 1989; Golumbek et al., 1991). The major mechanism by which IL-4 manifests its in vivo antitumor activity seems to be infiltration of inflammatory cells such as macrophages, eosinophils and neutrophils (Tepper et al., 1991; Noffz et al., 1998). However, it is also demonstrated that IL-4 can directly modulate proliferation of cancer cells of different types, including breast, gastric and renal cancers (Obiri et al., 1993; Morisaki et al., 1994; Cheon et al., 1996; Gooch et al., 1998). The molecular mechanism of the direct growth inhibitory effect of IL-4 has not been extensively studied.

p $21^{\text {WAF } 1 / C I P 1}$ is a member of the CIP/KIP family inhibitor of cyclin dependent kinases (CDKs) with a broad specificity. It can arrest cell cycle pregression at both $G_{1}$ and $G_{2}$ phases (Deng et al., 1995; Medema et al., 1998). p21 WAF1 is transcriptionally induced by both p53-dependent and -independent pathways (Rao et al., 1998). Whereas up-regulation of $\mathrm{p} 21^{\mathrm{WAF} 1}$ in response to a genotoxic stress is mediated by $p 53$, cellular accumulation of p21 WAF1 upon TGF- $\beta$ stimulation or during cellular differentiation and senescence is independent of p53 (Datto et al., 1995; Gartel et al., 1999; Eum et al., 2003). In both cases, the increase of p21 WAF1 correlates with growth arrest, suggesting that it may be the common mediator for different growth inhibitory signals.

IRF (interferon regulatory factor)- 1 is a member of 
the IRF family transcription factors with a tumor suppressor activity. It regulates cell cycle progression, apoptosis, and DNA repair. The IRF-1 gene is frequently deleted in human leukemia, and inactivation of IRF-1 accelerates cell transformation (Willman et al., 1993; Tanaka et al., 1994). However, the mechanism by which IRF-1 exerts its tumor suppressor activity is not well understood. The target genes of IRF-1 such as PKR, Stat1, lysyl oxidase, and p21 WAF1 may be responsible for its anti-oncogenic effect. In addition, IRF-1 reduces the promoter activation of CDK2 by interfering the activity of SP-1 (Xie et al., 2003).

In the present study, we investigated the mechanism of IL-4-induced growth inhibition in RCC cells, and demonstrated that IL-4 increased the expression of p21 WAF1 and IRF-1 transcriptionally to induce growth suppression. $\mathrm{p} 27^{\mathrm{KIP} 1}, \mathrm{p} 16^{\mathrm{INK} 4 \mathrm{a}}$, and $\mathrm{pRb}$ were not involved in the IL-4-mediated growth inhibition in RCC cells.

\section{Materials and Methods}

\section{Cell lines and culture}

Caki- 1 and A498 are established human RCC cell lines, and obtained from the Korean Cell Line Bank (Seoul National University, Seoul, Korea). Cells were cultured in RPMI-1640 medium containing $10 \%$ fetal bovine serum (FBS), penicillin $(100 \mathrm{U} / \mathrm{ml})$, and streptomycin $(100 \mu \mathrm{g} / \mathrm{ml})$.

\section{Antibodies}

Antibodies against p21 WAF1 $(C-19), p 27^{\text {KIP1 }}$ (C-19), IRF-1 (C-20), and $\beta$-actin (I-19) were purchased from Santacruz, and anti-p53 (DO-1) antibody was purchased from Oncogene.

\section{Cell cycle analysis}

Cells were incubated with human recombinant IL-4 (Biosource International, Camarillo, CA), and analyzed for the cell cycle distribution as described previously (Sohn et al., 1998). Briefly, cells were fixed in $70 \%$ ethanol overnight at $-20^{\circ} \mathrm{C}$, washed with phosphate bufferd saline (PBS), and suspended in PBS containing $200 \mu \mathrm{g} / \mathrm{ml} \mathrm{RNase} \mathrm{A} \mathrm{and} 20 \mu \mathrm{g} / \mathrm{ml}$ propidium iodide. After incubating for $30 \mathrm{~min}$ in dark, the cellular DNA content was analyzed by flow cytometry. Cell cycle was analyzed using a Cell Quest program (Beckton Dickinson, Mountain Veiw, CA)

\section{Immunoblot analysis}

Cells were lysed in the extraction buffer $(31.75 \mathrm{mM}$
Tris- $\mathrm{HCl}, \mathrm{pH} 6.81 \%$ sodium dodecyl sulfate (SDS), $10 \%$ glycerol, and $2.5 \% \quad \beta$-mercaptoethanol), and the whole cell lysates were subjected to SDS-polyacrylamide gel electrophoresis (PAGE). The size-fractionated proteins on the gel were transferred onto a nitrocellulose membrane. The membrane was blocked in $5 \%$ skim milk in Tris-buffered saline containing $0.05 \%$ Tween 20 , and incubated with a primary antibody. After washing, the membrane was incubated with the peroxidase-conjugated secondary antibody. The protein band of interest was detected using the enhanced chemiluminecence (ECL) reagents (Amersham, Arligton Heights, IL).

\section{Reverse transcription-polymerase chain reaction (RT-PCR)}

Total cellular RNA was extracted using the acid guanidinium isothiocyanate method (Chomczynski and Sacchi, 1987). cDNA was synthesized from the total cellular RNA using oligo (dT) primer (Promega, Madison, WI) and Moloney murine leukemia virusreverse transcriptase (MMLV-RT) (Gibco BRL, Grand Island, NY). The cDNA served as a template for PCR amplification of $\mathrm{p} 21^{\mathrm{WAF} 1}$ and IRF-1 genes. The sequences of PCR primers were as follows: $\mathrm{p} 21^{\text {WAF1 }}$, 5'-CGAAGTCAGTTCCTTGTGGA-3' and 5'-GGCAGA AGATGTAGAGCGGG-3'; IRF-1, 5'-AAGCATGCTGC CAAGCATGGCTGG-3' and 5'-ATCAGGCAGAGTGG AGCTGCT-3'. Thirty PCR cycles, each composed of $30 \mathrm{~s}$ denaturation at $95^{\circ} \mathrm{C}, 30 \mathrm{~s}$ annealing at $58^{\circ} \mathrm{C}$, and $1.5 \mathrm{~min}$ extension at $72^{\circ} \mathrm{C}$ were carried. PCR products were analyzed by agarose gel electrophoresis.

\section{in vitro CDK2 activity assay}

Cell lysates containing $1 \mathrm{mg}$ of protein were incubated overnight with an anti-CDK2 antibody (Transduction Laboratories, Lexington, $\mathrm{KY}$ ) at $4{ }^{\circ} \mathrm{C}$, and protein A-Sepharose 4B (30 $\mu$ l) (Pharmacia Biotech., Uppsala, Sweden) was added to the lysates. After incubating for $1 \mathrm{~h}$, the mixture was centrifuged, and the pellet containing CDK2 was washed sequentially with a NP40 lysis buffer $(150 \mathrm{mM} \mathrm{NaCl}, 1.0 \% \mathrm{NP} 40$, $50 \mathrm{mM}$ Tris, $\mathrm{pH} 8.0$ ), and with a kinase assay buffer (50 mM HEPES-NaOH, pH 7.3, $10 \mathrm{mM} \mathrm{MgCl} 2,5 \mathrm{mM}$ $\mathrm{MnCl}_{2}$, and $1 \mathrm{mM}$ dithiothreitol). The pellet was resuspended in the kinase assay buffer $(20 \mu l)$ containing $2.5 \mu \mathrm{g}$ histone $\mathrm{H} 1$ and $5 \mu \mathrm{Ci} \gamma{ }^{32}$ PATP. The kinase reaction was carried out for $20 \mathrm{~min}$ at room temperature and was terminated by adding an equal volume of the $2 \times$ SDS sample buffer and boiling. Phosphorylation of the histone $\mathrm{H} 1$ was analyzed by SDS-PAGE and autoradiography. 


\section{Transfection of the $\mathrm{p} 21^{\text {WAF1 }}$ and IRF-1 antisense oligonucleotides}

Phosphorothioate oligonucleotides were synthesized by Scandinavian Gene Synthesis AB (Koping, Sweden). The antisense and sense oligonucleotide sequences of $\mathrm{p} 21^{\mathrm{WAF} 1}$ and IRF-1 are as follows: 5'-TCCCCA GCCGGTTCTGACAT-3' (p21 antisense); 5'-ATGTCA GAACCGGCTGGGGA-3' (p21 sense); 5'-GAAAGA TGCCCGAGATGC-3' (IRF-1 antisense); 5'-GCATCT CGGGCATCTTTC-3' (IRF-1 sense). Two hours after seeding, cells were transfected with antisense or sense oligonucleotides using Lipofectin ${ }^{T M}$ (GibcoBRL, Grand Island, NY), according to the manufacturer's instruction.

\section{Proliferation assay}

Cells plated on a 96-well microtiter plate were transfected with the $221^{\text {WAF1 }}$ antisense or sense oligonucleotide. After incubating for $4 \mathrm{~h}, \mathrm{IL}-4(10 \mathrm{ng} / \mathrm{ml})$ was added to each well, and incubated for $24 \mathrm{~h}$. Cells were labeled with $\left[{ }^{3} \mathrm{H}\right]$ thymidine $(1 \mu \mathrm{Ci} /$ well $)$ for the last $6 \mathrm{~h}$ of incubation, and $\left[{ }^{3} \mathrm{H}\right.$ ]thymidine incorporation into DNA was measured by $\beta$-scintillation counting.

\section{Results}

Effect of IL-4 on cell cycle progression

Previously, we showed that IL-4 inhibited growth of all 3 human RCC cell lines, A498, CURCII and Caki-1

Table 1. Cell cycle analysis of Caki-1 cells treated with IL-4.

\begin{tabular}{|c|c|c|c|c|c|c|c|c|c|}
\hline & \multicolumn{9}{|c|}{ Cell cycle distribution } \\
\hline & \multicolumn{3}{|c|}{$\mathrm{G}_{1}(\%)$} & \multicolumn{2}{|c|}{ S $(\%)$} & \multicolumn{2}{|c|}{$\mathrm{G}_{2} / \mathrm{M} \quad(\%)$} & \multicolumn{2}{|c|}{$\mathrm{G}_{1} / \mathrm{S}$ ratio } \\
\hline & & Control & IL-4 & Control & IL-4 & Control & $\mathrm{IL}-4$ & Control & IL-4 \\
\hline 4 & h & 51 & 53 & 16 & 14 & 33 & 33 & 3.19 & 3.79 \\
\hline 24 & h & 50 & 70 & 26 & 17 & 24 & 13 & 1.92 & 4.12 \\
\hline 48 & h & 52 & 70 & 35 & 16 & 13 & 14 & 1.49 & 4.38 \\
\hline 72 & $\mathrm{~h}$ & 55 & 74 & 33 & 13 & 12 & 13 & 1.67 & 5.69 \\
\hline
\end{tabular}

Cells were treated with $\mathrm{L}-4(3 \mathrm{ng} / \mathrm{ml})$ as described in Materials and Methods, and cell cycle was analyzed by a flow cytometry at the indicated time points. These data are the representative of 3 independent experiments.
A

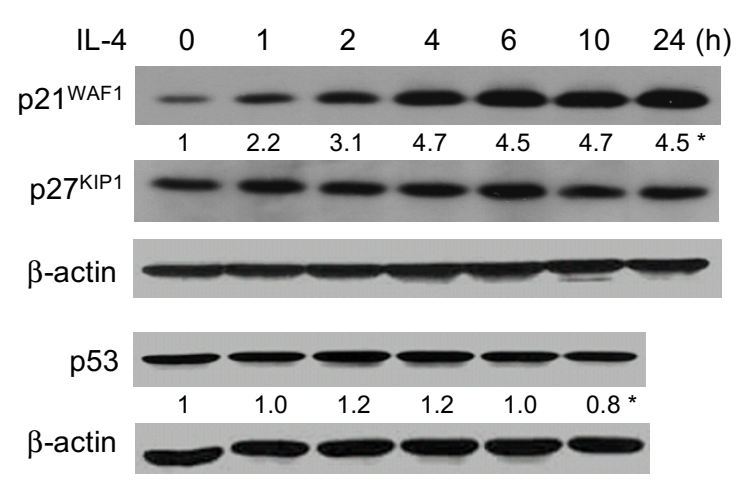

A498

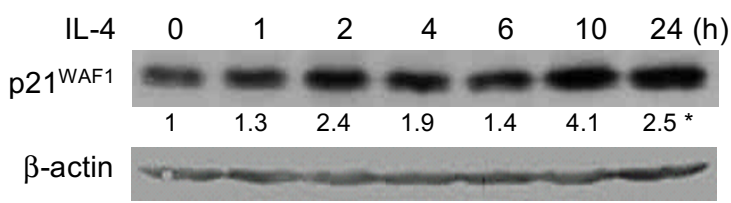

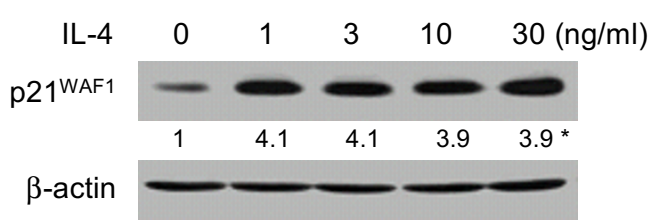

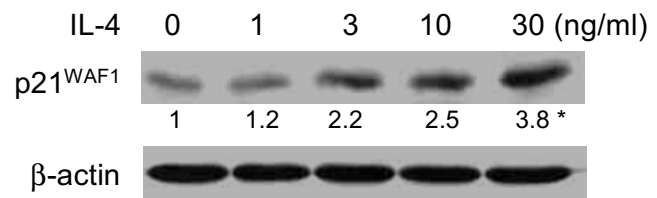

B

\section{Caki-1}

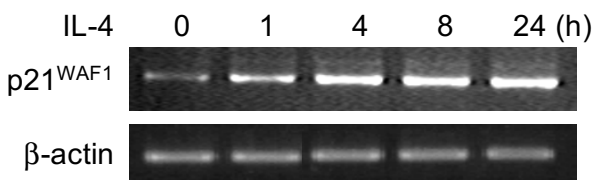

Figure 1. Effect of IL-4 on the p21 ${ }^{\text {WAF1 }}$ expression. (A) Cells were treated with IL-4 for the indicated times at $10 \mathrm{ng} / \mathrm{ml}$ (left panel), or at the indicated concentrations for $5 \mathrm{~h}$ (Caki-1) or $10 \mathrm{~h}$ (A498) (right panel). Protein expressions of $\mathrm{p} 21^{\text {WAF1 }}, \mathrm{p} 27^{\mathrm{KIP} 1}$, and $\mathrm{p} 53$ were analyzed by immunoblotting. (B) Expression levels of p21 ${ }^{\text {WAF }}$ mRNA were measured in Caki-1 cells by RT-PCR as described in Materials and Methods. *Indicates relative intensities of bands normalized by $\beta$-actin. 
(Cheon et al., 1996). To investigate the mechanism of anti-proliferative effect of IL-4, cell cycle distribution was analyzed in IL-4 treated Caki-1 cells. Four hours after IL-4 treatment, no significant changes in the cell cycle distribution were observed by flow cytometry analysis. However, at 24, 48, and $72 \mathrm{~h}$, fractions of cells in the $G_{1}$ phase were increased $35-40 \%$ compared to the control $(70 \%$ vs. $50 \%$ at $24 \mathrm{~h})$, whereas $S$ phase fractions were decreased $35-61 \%$ $(17 \%$ vs. $26 \%$ at 24 h) (Table 1). These data showed that IL-4 blocked cell cycle progression at the G1/S transition.

\section{Effect of IL-4 on p21 WAF1 expression}

Since IL-4 induced $\mathrm{G} 1$ cell cycle arrest, expressions of cell cycle regulatory proteins were analyzed by immunoblotting in Caki-1 cells. As shown in Figure $1 \mathrm{~A}$, the expression of $\mathrm{p} 21^{\text {WAF1 }}$ was elevated as early as $1 \mathrm{~h}$ after IL-4 treatment, whereas $\mathrm{p} 27^{\mathrm{KIP} 1}$ expression did not change. Increased expression of the p21 WAF1 protein was also observed in another RCC cell line, A498. Up-regulation of the $\mathrm{p} 21^{\mathrm{WAF} 1}$ protein was transcriptional, since its mRNA level was also increased at $1 \mathrm{~h}$ after IL-4 treatment (Figure 1B). p53

\section{A}
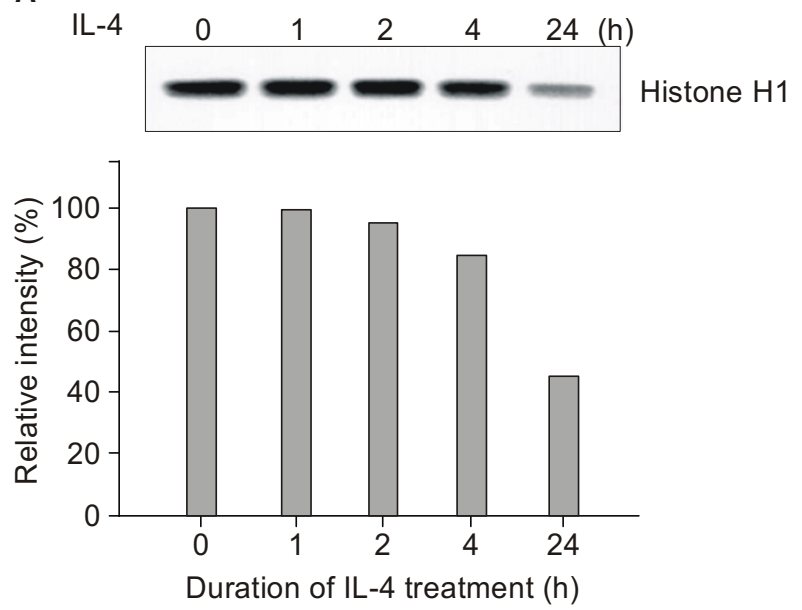

B

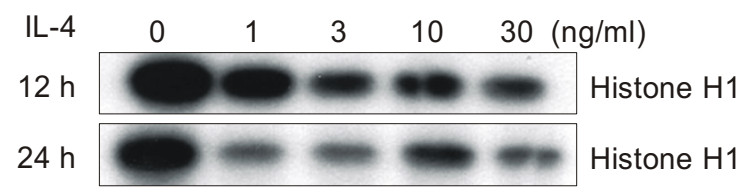

Figure 2. Effect of IL-4 on the CDK2 activity. Caki-1 cells were treated with IL-4 for the indicated times at $3 \mathrm{ng} / \mathrm{ml}(\mathrm{A})$, or at the indicated concentrations for 12 or $24 \mathrm{~h}$ (B). The activity of CDK2 was determined by in vitro kinase assay as described in Materials and Methods. The autoradiogram was analyzed by densitometry ( $A$, lower panel). expression was not enhanced by IL-4 indicating that the up-regulation of $\mathrm{p} 21^{\text {WAF1 }}$ was $\mathrm{p} 53$-independent (Figure $1 \mathrm{~A}$ ). No significant changes were observed in p16 ${ }^{\text {INK4a }}$ and cyclin D1 protein expressions, and pRb phosphorylation (data not shown).

\section{Effect of IL-4 on CDK2 activity}

Since CDK2 activity was required for the G1/S transition, and p21 ${ }^{\text {WAF1 }}$ was known to inhibit CDK2 activity, we analyzed CDK2 activity in Caki-1 cells treated with IL-4. After immunoprecipitation, CDK2 kinase activity was measured in vitro using histone $\mathrm{H} 1$ as a substrate. CDK2 activity was reduced by IL-4 treatment in a time- and dose-dependent manner (Figure $2 \mathrm{~A}$ and $\mathrm{B}$ ). After $4 \mathrm{~h}$ of $\mathrm{IL}-4$ treatment, CDK2 activity

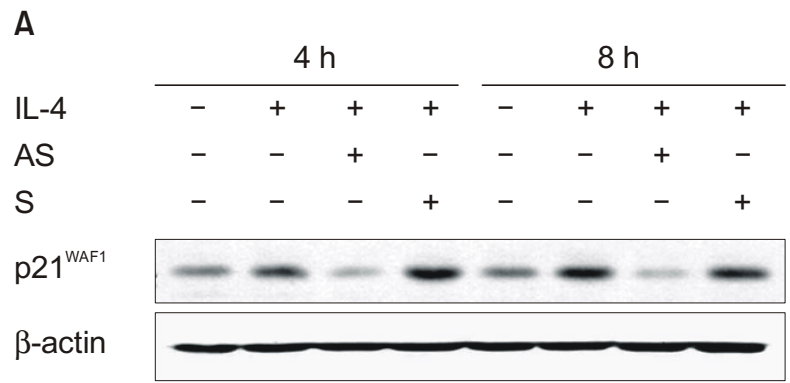

B

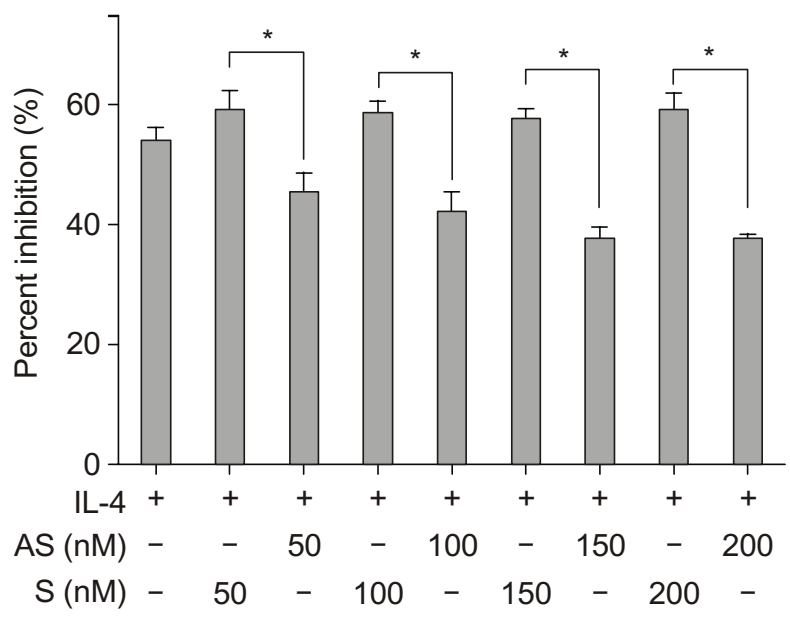

Figure 3. Effect of the p21 ${ }^{\text {war }}$ antisense oligonucleotide on the growth suppression by IL-4. Caki-1 cells were transfected with sense (S) or antisense (AS) oligonucleotide of p21 WAF1 , and $4 \mathrm{~h}$ later, treated with IL-4 $(10 \mathrm{ng} / \mathrm{ml})$. (A) Cell lysates were prepared at 4 and $8 \mathrm{~h}$ after IL-4 treatment, and the p21 ${ }^{\text {WAF1 }}$ expression was analyzed by immunoblotting. (B) Proliferation was measured by $\left[{ }^{3} \mathrm{H}\right]$ thymidine incorporation assay as described in Materials and Methods. Percent inhibition (\%) was calculated as follows: $\{1-(\mathrm{CPM}$ of treated cells/CPM of control cells) $\} \times 100$. ${ }^{*}$ Indicates $P<0.05$ (Student's $t$-test). Data shown here are the representatives of 3 independent experiments. 
started to decrease, and by $24 \mathrm{~h}$, it was reduced to about $50 \%$ of the control level (Figure 2A). On immunoblot analysis, the protein level of CDK2 did not change by IL-4 treatment (data not shown), indicating that the increased $\mathrm{p} 21^{\mathrm{WAF} 1}$ expression was responsible for the reduced CDK2 activity.

\section{Effect of the p21 WAF1 antisense oligonucleotide on IL-4-induced growth inhibition}

To confirm that the increased expression of $\mathrm{p} 21^{\text {WAF1 }}$ mediated the growth suppression by IL-4, Caki- 1 cells were transfected with the $\mathrm{p} 21^{\mathrm{WAF} 1}$ antisense or sense oligonucleotide before treating with IL-4. Transfection with the p21 WAF1 antisense, but not the sense, oligonucleotide prevented the increase of p21 WAF1 expression by IL-4 (Figure $3 \mathrm{~A}$ ). At the same time, the p21 WAF1 antisense oligonucleotide reversed IL-4 induced growth suppression. The effect of the p $21^{\text {WAF1 }}$ antisense oligonucleotide was dose-dependent, reaching to the maximum inhibition level at $150 \mathrm{nM}$ (Figure 3B). It was noted that the IL-4-induced growth inhibition was not completely reversed by the p21 WAF1 antisense oligonucleotide, suggesting that other molecules were also involved in the antiproliferative effect of IL-4.

\section{Role of IRF-1 in IL-4-induced growth inhibition of RCC cells}

To search for molecules other than p21 WAF1 that mediate the growth inhibitory effect of IL-4 in RCC cells, expressions of several growth regulatory proteins were analyzed. Among those, we found that the expression of IRF-1 protein was elevated by IL-4 treatment both in Caki-1 and A498 (Figure 4A). IRF-1 is a transcription factor with a growth inhibitory effect, and was previously shown that the expression could be modulated by IL-4 (Ohmori et al., 1997; Ackermann et al., 1999; Goenka et al., 1999). The IRF-1 protein was up-regulated from $1 \mathrm{~h}$ post IL-4 treatment. The level of IRF-1 mRNA was also increased, indicating that the elevated expression of IRF-1 was transcriptional (Figure 4B). To test whether the elevation of IRF-1 expression was responsible for the growth inhibition by IL-4, the effect of the IRF-1 antisense oligonucleotide was investigated. The increase of IRF-1 expression induced by IL-4 was

\section{A Caki-1}
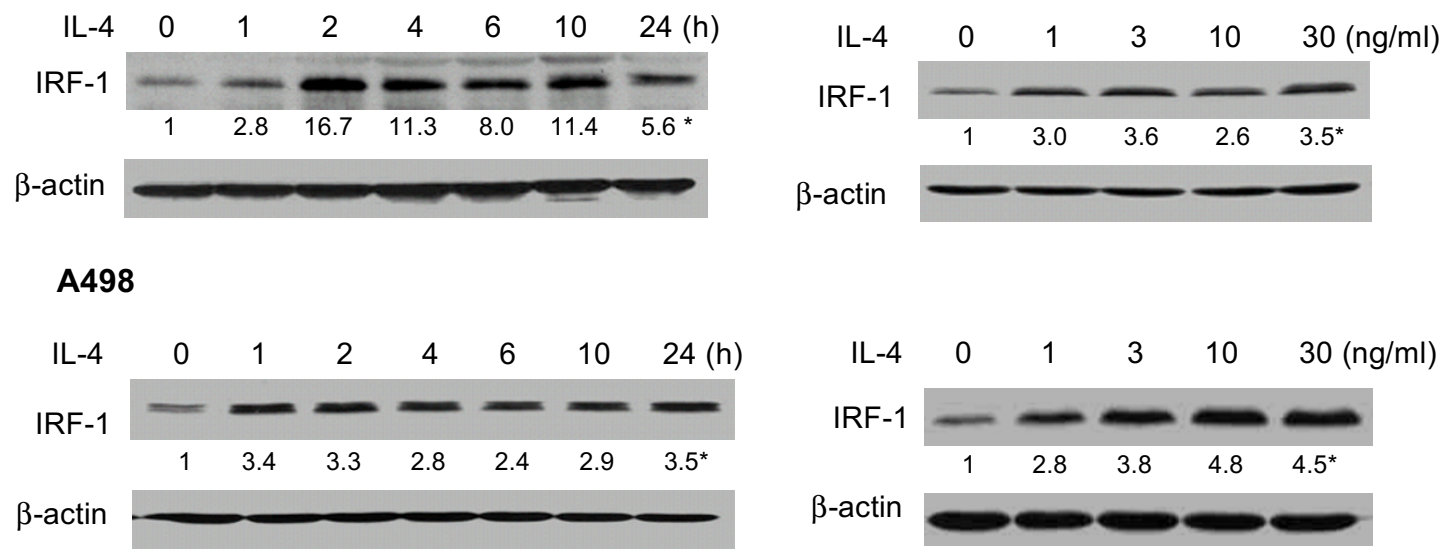

B

Caki-1

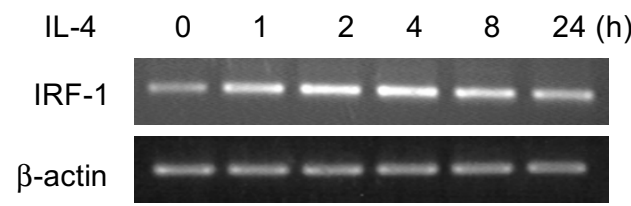

Figure 4. Effect of IL-4 on the IRF-1 expression. (A) Cells were treated with IL-4 for the indicated times at $10 \mathrm{ng} / \mathrm{ml}$ (left panel), or at the indicated concentrations for $5 \mathrm{~h}$ (Caki-1) or $10 \mathrm{~h}$ (A498) (right panel). Protein expression of IRF-1 was analyzed by immunoblotting. (B) Expression level of IRF-1 mRNA was measured in Caki-1 cells by RT-PCR as described in Materials and Methods. ${ }^{*}$ Indicates relative intensities of bands normalized by $\beta$-actin. 

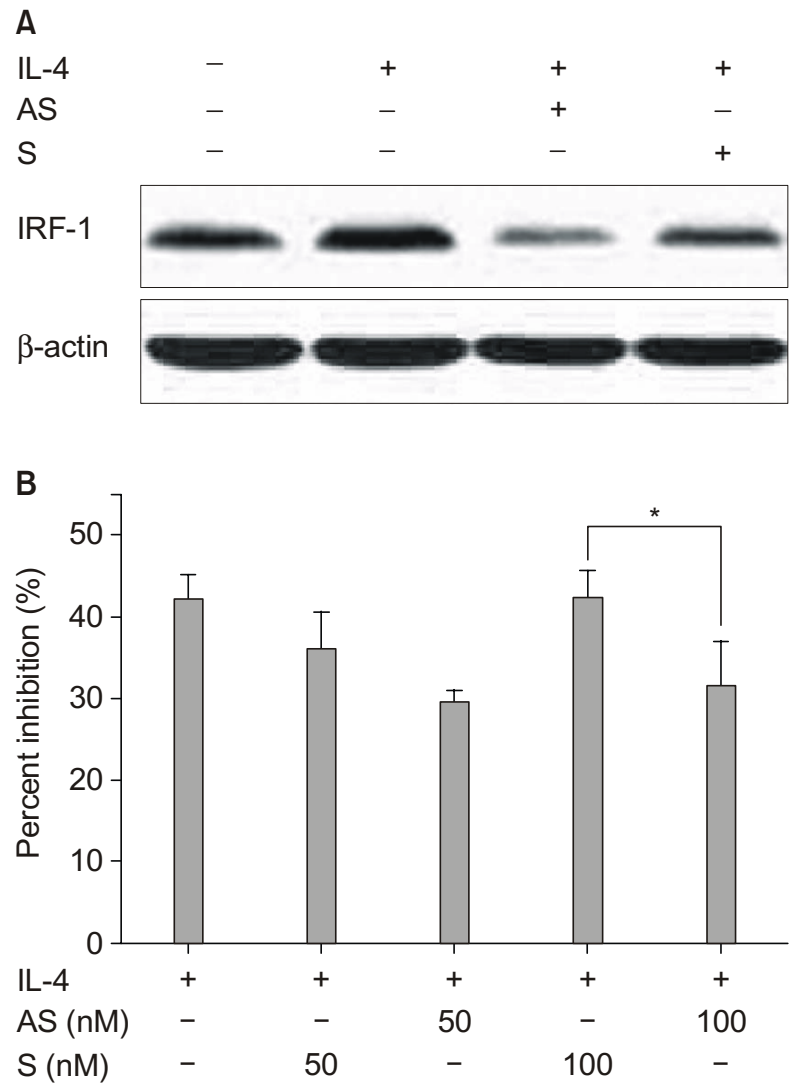

Figure 5. Effect of the IRF-1 antisense oligonucleotide on the IL-4-induced growth suppression. Caki-1 cells were transfected with sense (S) or antisense (AS) oligonucleotide of IRF-1, and $4 \mathrm{~h}$ later, treated with IL-4 $(10 \mathrm{ng} / \mathrm{ml})$. (A) Cell lysates were prepared at $4 \mathrm{~h}$ after IL-4 treatment, and the IRF-1 expression was analyzed by immunoblotting. (B) Cell proliferation was measured by $\left[{ }^{3} \mathrm{H}\right]$ thymidine incorporation assay as described in Materials and Methods. Percent inhibition (\%) was calculated as follows: $\{1$-(CPM of treated cells/CPM of control cells) $\} \times 100$. ${ }^{*}$ Indicates $P<0.05$ (Student's $t$-test). Data shown here are the representatives of 3 independent experiments.

abrogated in cells transfected with the IRF-1 antisense oligonucleotide (Figure $5 \mathrm{~A}$ ). As shown in Figure $5 B$, the IRF-1 antisense oligonucleotide prevented IL-4-induced growth inhibition by $26 \%$ at $100 \mathrm{nM}$ $(32 \%$ in the antisense oligonucleotide treated cells vs. $43 \%$ in the sense oligonucleotide treated cells). These results show that IRF-1, in addition to $\mathrm{p} 21^{\text {WAF1 }}$, is induced by IL-4 to suppress proliferation of the human RCC cells.

\section{Discussion}

Although almost all cell types that have been examined expressed a high affinity IL-4 receptor (Gooch et al., 1998; Trejdosiewicz et al., 1998), IL-4 affects growth of some cell types only. The mechanism for a direct growth inhibitory effect in IL-4 sensitive cancer cell lines has not been extensively studied. Morisaki et al. (1994) reported that IL-4 regulated G1 cell cycle progression in gastric carcinoma cells by inducing hypophosphorylation of $\mathrm{pRb}$, and decreasing the expressions of cyclin-D1, p34 $4^{\text {cdc2 }}$ and c-myc. In nontransformed $B$ cells or astrocytes, changes in the expression level of $\mathrm{p} 27^{\mathrm{KIP} 1}$ were observed in IL-4induced growth modulation (Blanchard et al., 1997; Liu et al., 1997). However, we did not find changes in the protein expressions of cyclin D1, p3 $4^{\mathrm{cdc} 2}, \mathrm{c}-\mathrm{myc}$ (unpublished data), or $\mathrm{p} 27^{\mathrm{KIP} 1}$ in $\mathrm{IL}-4$ treated RCC cells. In another report by Liu et al. (2000), p53dependent induction of $\mathrm{p} 21^{\text {WAF1 }}$ was required for the $\mathrm{IL}-4$-mediated increase of the $\mathrm{p} 27^{\mathrm{KIP} 1}$ protein which was responsible for the growth arrest by IL-4 in low grade astrocytoma cells. Therefore, they suggested that both $\mathrm{p} 21^{\mathrm{WAF} 1}$ and $\mathrm{p} 27^{\mathrm{KIP} 1}$ were employed as dual inhibitors of astrocytoma cycling at the G1/S interphase. Our results are consistent with theirs in that p $21^{\text {WAF1 }}$ is a key mediator of IL-4-induced growth inhibition, although there are some discrepancies. In this study, the increase of p21 WAF1 expression is p53-independent, and the expression of $\mathrm{p} 27^{\mathrm{KIP} 1}$ does not change by IL-4.

The importance of $\mathrm{p} 21^{\text {WAF1 }}$ up-regulation in the IL-4-induced growth inhibition was demonstrated by using an antisense oligonucleotide that significantly reversed the effect of IL-4. However, p21 $1^{\text {WAF1 }}$ antisense oligonucleotide did not prevent the IL-4-induced growth suppression completely, suggesting that there were additional mechanisms responsible for the antiproliferative effect of IL-4. Our data indicate that the increased expression of IRF-1 is also responsible for the growth suppression by IL-4. However, how IRF-1 suppresses cellular growth is not known. An interesting possibility was suggested by Miyazaki et al. (1998) that IRF-1 activated p2 $1^{\text {WAF1 }}$ expression in a p53-independent pathway. Currently, this possibility is being tested in our system. According to the previous reports, IL-4 could either inhibit or induce the expression of IRF-1: IFN- $\gamma$-induced and Stat1-dependent activation of the IRF-1 promoter was inhibited by IL-4 in some cases (Ohmori et al., 1997; Goenka et al., 1999), whereas in another case, IL-4 was shown to enhance the expression of IRF-1 (Ackermann et al., 1999). Concurrent induction of IRF-1 and p $21^{\text {WAF1 }}$ has been observed in growth inhibition of squamous cervical carcinoma cell lines by IFN- $\beta$ / retinoic acid treatment (Giandomenico et al., 1998). In summary, we showed here that IL-4 increased IRF-1 and p21 $1^{\text {WAF1 }}$ expressions via transcriptional activation to induce growth inhibition and $\mathrm{G} 1$ cell cycle arrest. To our knowledge, concurrent induction of $\mathrm{p} 21^{\mathrm{WAF} 1}$ and IRF-1 by IL-4 has not been reported. Increased expression of $\mathrm{p} 21^{\mathrm{WAF} 1}$ would result in the 
reduction of CDK2 activity, and thereby induce $\mathrm{G} 1$ cell cycle arrest. Questions such as how IRF-1 suppresses cellular growth, and which signaling pathway is responsible for the transcriptional activation of p $21^{\text {WAF1 }}$ and IRF-1 need to be answered.

\section{Acknowledgement}

This work was supported by the National Nuclear R\&D Program of the Ministry of Science and Technology and the Korea Science and Engineering Foundation (Grant No. M2-0104-00-0035-01-A04-00017-3-0) and the Brain Korea 21 Project. We thank Drs. Soo II Chung and Sangduk Kim for critical reading of the manuscript.

\section{References}

Ackermann LW, Wollenweber LA, Denning GM. IL-4 and IFN-gamma increase steady state levels of polymeric Ig receptor mRNA in human airway and intestinal epithelial cells. J Immunol 1999;162:5112-8

Blanchard DA, Affredou MT, Vazquez A. Modulation of the p27kip1 cyclin-dependent kinase inhibitor expression during IL-4-mediated human B cell activation. J Immunol 1997;158: 3054-61

Brown MA, Hural J. Functions of IL-4 and control of its expression. Crit Rev Immunol 1997;17:1-32

Cheon J, Chung DJ, Kim JJ, Koh SK, Sohn J. Inhibitory effects of interleukin-4 on human renal cell carcinoma cells in vitro: in combination with interferon- $\alpha$, tumor necrosis factor- $\alpha$ or interleukin-2. Int J Urol 1996;3:196-201

Chomczynski $P$, Sacchi N. Single-step method of RNA isolation by acid guanidinium thiocyanate-phenol-chloroform extraction. Anal Biochem 1987;162:156-9

Datto MB, Li Y, Panus JF, Howe DJ, Xiong Y, Wang XF. Transforming growth factor beta induces the cyclin-dependent kinase inhibitor p21 through a p53-independent mechanism. Proc Natl Acad Sci USA 1995;92:5545-9

Deng C, Zhang $P$, Harper JW, Elledge SJ, Leder P. Mice lacking $\mathrm{p} 21^{\text {CIP1MNAFi }}$ undergo normal development, but are defective in G1 checkpoint control. Cell 1995;82:675-84

Eum WS, Li MZ, Sin GS, Choi SY, Park JB, Lee JY, Kwon HY. Dexamethasone-induced differentiation of pancreatic AR42J cell involves p21 $1^{\text {waf1/cip } 1}$ and MAP kinase pathway. Exp Mol Med 2003;35:379-84

Gartel AL, Tyner AL. Transcriptional regulation of the p21 ${ }^{\text {WAF1/CIP1 }}$ gene. Exp Cell Res 1999;246:280-9

Giandomenico V, Vaccari G, Fiorucci G, Percario Z, Vannuchi S, Matarrese P, Malorni W, Romeo G, Affabris GR. Apoptosis and growth inhibition of squamous carcinoma cells treated with interferon-alpha, IFN-beta and retinoic acid are associated with induction of the cyclin-dependent kinase inhibitor p21. Eur Cytokine Netw 1998;9:619-31

Goenka S, Youn J, Dzurek LM, Schindler U, Yu-Lee LY,
Boothby M. Paired Stat6 C-terminal transcription activation domains required both for inhibition of an IFN-responsive promoter and trans-activation. J Immunol 1999;163:4663-72

Golumbek PT, Lazenby AJ, Levitsky HI, Jaffee LM, Karasuyama H, Baker M, Pardoll DM. Treatment of established renal cancer by tumor cells engineered to secrete interleukin-4. Science 1991;254:713-6

Gooch JL, Lee AV, Yee D. Interleukin 4 inhibits growth and induces apoptosis in human breast cancer cells. Cancer Res 1998;58:4199-205

Liu J, Flanagan WM, Drazba JA, Estes ML, Barnett GH, Haqqi T, Kondo S, Barna BP. The CDK inhibitor, p27Kip1, is required for IL-4 regulation of astrocyte proliferation. J Immunol 1997;159:812-9

Liu J, Estes ML, Drazba JA, Liu H, Prayson R, Kondo S, Jacobs BS, Barnett GH, Barna BP. Anti-sense oligonucleotide of p21(waf1/cip1) prevents interleukin 4-mediated elevation of p27(kip1) in low grade astrocytoma cells. Oncogene 2000;19:661-9

Medema RH, Klompmaker R, Smits VA, Rijksen G. p21waf1 can block cells at two points in the cell cycle, but does not interfere with processive DNA-replication or stress-activated kinases. Oncogene 1998;16:431-41

Miyazaki M, Ohashi R, Tsuji T, Mihara K, Gohda E, Namba M. Transforming growth factor beta 1 stimulates or inhibits cell growth via down- or up-regulation of $\mathrm{p} 21 / \mathrm{Waf} 1$. Biochem Biophys Res Commun 1998;246:873-80

Morisaki T, Uchiyama A, Yuzuki D, Essner R, Morton DL, Hoon DS. Interleukin 4 regulates $G 1$ cell cycle progression in gastric carcinoma cells. Cancer Res 1994;54:1113-8

Noffz G, Qin Z, Kopf M, Blankenstein T. Neutrophils but not eosinophils are involved in growth supepression of IL-4-secreting tumors. J Immunol 1998;160:345-50

Obiri NI, Hillman GG, Haas GP, Sud S, Puri RK. Expression of high affinity interleukin-4 receptors on human renal cell carcinoma cells and inhibition of tumor cell growth in vitro by interleukin-4. J Clin Invest 1993;91:88-93

Ohmori Y, Hamilton TA. IL-4-induced STAT6 suppresses IFN-gamma-stimulated STAT1-dependent transcription in mouse macrophages. J Immunol 1997;159:5474-82

Rao S, Lowe M, Herliczek TW, Keyomarsi K. Lovastatin mediated G1 arrest in normal and tumor breast cells is through inhibition of CDK2 activity and redistribution of p21 $1^{\text {WAF1 }}$ and $\mathrm{p} 27^{\mathrm{KIP} 1}$, independent of p53. Oncogene 1998; 17:2393-402

Sohn J, Lee CH, Chung DJ, Park SH, Kim I, Hwang WI. Effect of petroleum ether extract of Panax ginseng roots on proliferation and cell cycle progression of human renal cell carcinoma cells. Exp Mol Med 1998;30:47-51

Tanaka N, Ishihara M, Kitagawa M, Harada H, Kimura T, Matsuyama T, Lamphier MS, Aizawa S, Mak TW, Taniguchi T. Cellular commitment to oncogene-induced transformation or apoptosis is dependent on the transcription factor IRF-1. Cell 1994;77:829-39

Tepper RI, Pattengale PK, Leder P. Murine interleukin-4 displays potent anti-tumor activity in vivo. Cell 1989;57: 503-12 
Tepper RI, Coffman RL, Leder P. An eosinophil-dependent mechanism for the antitumor effect of interleukin-4. Science 1992;257:548-51

Trejdosiewicz LK, Morton R, Yang Y, Banks RE, Selby PJ, Southgate J. Interleukins 4 and 13 upregulate expression of CD44 in human colonic epithelial cell lines. Cytokine 1998;10:756-65

Willman CL, Sever CE, Pallavicini MG, Harada H, Tanaka
N, Slovak ML, Yamamoto H, Harada K, Meeker TC, List AF. Deletion of IRF-1, mapping to chromosome $5 \mathrm{q} 31.1$, in human leukemia and preleukemic myelodysplasia. Science 1993; 259:968-71

Xie RL, Gupta S, Miele A, Shiffman D, Stein JL, Stein GS, van Wijnen AJ. The tumor suppressor interferon regulatory factor 1 interferes with SP1 activation to repress the human CDK2 promoter. J Biol Chem 2003;278:26589-96 